International Journal of Biological Research, $2(1)(2014) 18-20$
International Journal of Biological Research
JPC \begin{tabular}{c} 
Journal home page: $\begin{array}{c}\text { www.sciencepubco.com/index.php/IJBR } \\
\text { do.14419/ijbr.v2il.2276 } \\
\text { Research Paper }\end{array}$ \\
\hline
\end{tabular}

\title{
Screening of biological actives extracts from Annona squamosa
}

\author{
C. Babu ${ }^{1}$, P. Rama Devi ${ }^{2} *$, P. Kombiah ${ }^{3}$ \\ ${ }^{1}$ PioneerKumaraswamy College, Nagercoil - 629 003, Tamil Nadu, India \\ ${ }^{2}$ ST. Mary's College (Autonomous), Thoothukudi - 628 001, Tamil Nadu, India \\ ${ }^{3}$ ST. Xavier's College (Autonomous), Palayamkottai - 627 002, Tamil Nadu, India \\ *Corresponding author E-mail:p. remadev@yahoo.co.in
}

\begin{abstract}
The aim of the present study is to focus on the cytotoxicity and antimicrobial activities from Annona squamosa plant seed extracts. The plant A. squamosa seed was extracted with various solvents like chloroform, methanol, hexane, petroleum ether and acetone. The antimicrobial activities of all these extracts were determined by disc diffusion method against Pseudomonas aeruginosa, Proteius vulgaries, Staphylococcus aureus and Escherichia coli pathogens. Methanol, hexane and acetone extracts of A. squamosa showed highest antimicrobial activity against all pathogens. Cytotoxic activity of A. squamosa seed extract was tested using Artemia salina (Brine shrimp) bioassay. In cytotoxicity study, extract caused $86 \%$ mortality of Brine shrimp larvae after $24 \mathrm{~h}$ at a concentration of $500 \mu \mathrm{g} / \mathrm{mL}$.
\end{abstract}

Keywords: Antimicrobial Activity, Cytotoxicity Activity. Extract, Pathogens, Solvent.

\section{Introduction}

India is the largest producer of medicinal herbs and traditional practitioners of this country use more than 6000 medicinal plants in primary health care (Shariff et al., 2006). Medicinal plants are believed to be an important source of new chemical substances with potential therapeutic effects. The World Health Organization (WHO) estimates that about $80 \%$ of the population living in the developing countries relies almost exclusively on traditional medicine for their primary health care needs. In nature many plants and plants seed provided source of medicine at the earlier times. Plants have proven to be the most useful in curing diseases and provide an important source of pharmacy and medicine. Plants have great significance to the health of individuals. The medicinal importance of these plants lies in some chemical substances that produce a distinct physiological action on the body of human Annona squamosa is a commonly called as "Custand apple". Is a tropical branched shrub of family Annonaceae. A squamosa is traditionally used for the treatment of epilepsy, dysentery, worm infestation, constipation, hemorrhage, dysuria, fever, thirst, ulcers and also as an abortifacient (Yoganarasimhan, 2000). A. squamosa seeds possessed potent pro apoptotic characteristics for several human tumour cells; an ethanol extract of the leaves and stem is reported to have anticancer activity (Pardhasaradhi et al., 2005). Since there are no reports on antimicrobial and cytotoxic effects of A. squamosa seed. In this study to evaluate the antimicrobial and cytotoxic activities against some pathogenic microorganisms and Artemia salina (brine shrimp nauplii).

\section{Material and method}

\subsection{Collection of strains}

The antimicrobial activity of the plant Annona squamosa seed extracts were investigated against four pathogenic bacterial strains such as Pseudomonas aeruginosa, Proteius vulgaries, Staphylococcus aureus and Escherichia coli. All the bacterial strains were collected from Vivek Laboratory, Kanyakumari, Tamil Nadu, India.

\subsection{Preparation of plant extracts}

The plant A. squamosa seeds were collected from different regions of Kanyakumari, Tamil Nadu, India. After collection, the seeds were washed thoroughly 2-3 times with running water and once with sterile distilled water. Then seeds were dried in shade for five days and then powdered with the help of blender. The seed powder was prepared using the solvents hexane, petroleum ether, acetone, methanol and chloroform. $10 \mathrm{~g}$ of the sample was taken and homogenized with $100 \mathrm{ml}$ of the respective solvents. The crude preparation was left overnight in the shaker at room temperature and then centrifuged at 4000rpm for 20minuts. The supernatant was transferred in airtight container and kept in a dark and dry place until further studies.

2.3. Phytochemical analysis of the plant extract

The extracts were subjected to phytochemical tests for plant secondary metabolites, tannins, saponins, steroid, alkaloids and glycolsides in accordance with Harborne (1998) with little modification.

\subsection{Antimicrobial assay}

Invitro antibacterial activity was performed by disc diffusion assay method Rahman et al., 2008. Commercially available Muller Hinton Agar Medium (HiMedia) $33.9 \mathrm{~g}$ was added in $1000 \mathrm{ml}$ of distilled water. The dissolved medium was autoclaved at $15 \mathrm{lbs}$ pressure at $121{ }^{\circ} \mathrm{C}$ for 15 minutes. The autoclaved medium was mixed well and poured onto $100 \mathrm{~mm}$ petri plates $(25-30 \mathrm{ml} / \mathrm{plate})$ while still molten. The test microorganisms were seeded into respective medium by spread plate method $10 \mu \mathrm{l}(10$ cells $/ \mathrm{ml})$ with the $24 \mathrm{~h}$ cultures. Wells were cut and different concentration of extracts (namely aqueous, methanol and chloroform extracts) were loaded. 
The plates were then incubated at $37^{\circ} \mathrm{C}$ for 24 hours. The antibacterial activity was measured the diameter of the inhibition zone formed around the well.

\subsection{Cytotoxic assay}

Brine shrimp Artemia salina cysts were purchased and maintained in the laboratory conditions and were used for cytoxicity assay (Meyer et al., 1982). Briefly, Artemia salina cysts of $1 \mathrm{gm}$ were aerated in $1 \mathrm{~L}$ capacity of glass jar containing $3.2 \%$ of saline water $(3.2 \mathrm{gm} \mathrm{NaCl}$ in $100 \mathrm{ml}$ of distilled water). The jar was aerated constantly for $48 \mathrm{~h}$ at room temperature $\left(25-29^{\circ} \mathrm{C}\right)$. After hatching, active free-floating nauplii were collected from bright illumination and were used for the bioassay. Fifteen nauplii were transferred into each concentration of the sample. The experimental setup was allowed to remain $24 \mathrm{~h}$ in darkness and nauplii were counted under the microscope after incubation time. A percentage of mortality was determined byLC $\mathrm{C}_{50}$.

\section{Result}

The antimicrobial effects of different extracts of A. squamosa different test organisms are shown in Table 1. Methanol and acetoneexhibited statistically insignificant activity against the all tested bacterial strains. Hexane and petroleum etherextracts exhibited statistically significant antimicrobial activity against all bacterial strains. The chloroform extract was no antimicrobial activity against all bacterial strains. Cytoxicity activity of the plant $A$. squamosa seed extract is shown in Table 2. The extract showed $86 \%$ mortality at $500 \mu \mathrm{g} / \mathrm{mL}$ concentration and its LC50-value was $120.613 \mu \mathrm{g} / \mathrm{mL}$ which was considered moderately toxic. No mortality was found in negative control (DMSO) group.

\section{Discussion}

Plants are important source of potentially useful structures for the development of new chemotherapeutic agents. The first step towards this goal is the invitro antibacterial activity assay (Tona, 1998). Many reports are available on the antiviral, antibacterial, antifungal, anthelmintic, antimolluscal and anti (-) no inhibition.

Table 1:Antibacterial Activity of Different Extracts of A. Squamosa Seed Extracts

\begin{tabular}{|c|c|c|c|c|}
\hline \multirow{3}{*}{ Name of the bacterial strain } & \multirow{3}{*}{ Different extract } & \multicolumn{3}{|c|}{ Zone of inhibition (mm) } \\
\hline & & \multicolumn{3}{|c|}{ Extract concentration } \\
\hline & & $75 \mu \mathrm{g} / \mathrm{ml}$ & $150 \mu \mathrm{g} / \mathrm{ml}$ & $250 \mu \mathrm{g} / \mathrm{ml}$ \\
\hline \multirow{5}{*}{ Staphylococcs aureus } & Methanol & $8 \pm 0.7$ & $10 \pm 0.5$ & $15 \pm 0$ \\
\hline & Chloroform & - & - & - \\
\hline & Acetone & - & $10 \pm 0$ & $12 \pm 0$ \\
\hline & Petroleum ether & - & $8 \pm 1.0$ & $15 \pm 0.5$ \\
\hline & Hexane & $7 \pm 0.5$ & $9 \pm 0$ & \\
\hline \multirow{5}{*}{ Pseudomonas aeruginosa } & Methanol & - & $7 \pm 1.5$ & $10 \pm 0$ \\
\hline & Chloroform & - & - & - \\
\hline & Acetone & - & $6 \pm 0$ & $9.3 \pm 0.5$ \\
\hline & Petroleum ether & $6 \pm 0.2$ & $8 \pm 0.5$ & $12 \pm 0$ \\
\hline & Hexane & $6 \pm 0$ & $12 \pm 0.5$ & $15 \pm 1.1$ \\
\hline \multirow{5}{*}{ Proteius vulgaries } & Methanol & - & - & - \\
\hline & Chloroform & - & - & - \\
\hline & Acetone & - & - & $6 \pm 1.1$ \\
\hline & Petroleum ether & - & - & $8 \pm 0$ \\
\hline & Hexane & - & - & $8 \pm 0.5$ \\
\hline \multirow{5}{*}{ Escherichia coli } & Methanol & $9 \pm 0$ & $14.3 \pm 0.5$ & $17.6 \pm 0.5$ \\
\hline & Chloroform & - & - & - \\
\hline & Acetone & $9 \pm 0$ & $16.6 \pm 1.1$ & $25 \pm 0$ \\
\hline & Petroleum ether & - & - & - \\
\hline & Hexane & - & $7 \pm 2$ & $13.3 \pm 1.5$ \\
\hline
\end{tabular}

Table 2: Cytotoxic Assay of Different Concentrations of A. Squamosa Seed Extract

\begin{tabular}{lllllllll}
\hline Hours & $\begin{array}{l}\text { Dosage } \\
\text { level } \\
\mu \mathrm{g} / \mathrm{ml}\end{array}$ & $\begin{array}{l}\text { Total } \\
\text { shrimp }\end{array}$ & $\begin{array}{l}\text { No. of death } \\
\text { shrimp }\end{array}$ & $\begin{array}{l}\text { Log } \\
\text { dose }\end{array}$ & $\begin{array}{l}\text { Percentage of } \\
\text { mortality }\end{array}$ & $\begin{array}{l}\text { Regression line } \\
\text { equation }\end{array}$ & $\begin{array}{l}\text { 95\% Confidence limited } \\
\mu \mathrm{g} / \mathrm{ml}\end{array}$ & $\begin{array}{l}\mathrm{LC} \mathrm{C}_{50} \mu \mathrm{g} / \mathrm{ml} \\
\mathrm{*} 24 \mathrm{hrs}\end{array}$ \\
\hline $500 \mu \mathrm{g} / \mathrm{ml}$ & 15 & 13 & 2.70 & 86.60 & & & \\
& $250 \mu \mathrm{g} / \mathrm{ml}$ & 15 & 11 & 2.40 & 73.30 & $\mathrm{y}=1.881 \mathrm{x}+3.081$ & $3.2845+2.77$ & 120.613 \\
& $125 \mu \mathrm{g} / \mathrm{ml}$ & 15 & 8 & 2.10 & 53.30 & & & \\
& $75 \mu \mathrm{g} / \mathrm{ml}$ & 15 & 5 & 1.87 & 33.30 & & & \\
\hline
\end{tabular}

Inflammatory properties of plants (Beher and Misra, 2005). Some of these observations have helped in identifying the active principle responsible for such activities and in the developing drugs for the therapeutic use in human beings. However, not many reports are available on the exploitation of antifungal or antibacterial property of plants for developing commercial formulations for applicationsin crop protection.

Successful determination of such biologically active compounds from plant material is largely dependent on the type of solvent used in the extraction procedure. Organic solvents such as ethanol, acetone, and methanol are often used to extract bioactive compounds (Eloff, 1998). Medicinal plants have great significance to the health of individuals and communities. The medicinal importance of plants lies in some chemical substances that produce a specific physiological action on the human body. The most essential of these bioactive constituents of plants are alkaloids, saponins, tannins, flavonoids and phenolic compounds and many more components. Quinlan et al., 2004 worked on steroidal extracts from some medicinal plants which exhibited antibacterial activities on some bacterial isolates. Phytochemical investigations suggested that the presence of steroid in this plant extract. Many plants are used as medicines because of their antimicrobial nature, which are due to compounds synthesized in the secondary metabolism of the plant. These products are known by their active substances (Geethalakshmi et al., 2010). The present study investigated the antimicrobial activity of $A$. squamosa the methanol and acetone exhibited statistically insignificant activity against the all tested bacterial strains. Hexane and petroleum ether extracts exhibited statistically significant antimicrobial activity against all bacterial strains. The chloroform extract was no antimicrobial activity against all bacterial strains.

Several studies have shown that brine shrimp bioassay has been an excellent method to screen the cytotoxic property of medicinal plants and for the isolation of a great variety of biological- 
ly active compound (Quignard, 2004). The brine shrimp test represents a rapid, inexpensive and simple bioassay for testing the plant extract lethality which in most cases correlates reasonably well with cytotoxic and antitumor properties. Most often, a desired biological response is not due to one component but rather due to a mixture of bioactive plant components. Therefore, crude extracts must be screened for biological activity. The brine shrimp lethality assay has been proved to be a convenient system for monitoring biological activities of natural products (Chanda and Baravalia, 2011). Cytoxicity activity of the plant $A$. squamosa seed extract was showed $86 \%$ mortality at $500 \mu \mathrm{g} / \mathrm{mL}$ concentrations and its LC50-value was $120.613 \mu \mathrm{g} / \mathrm{mL}$. Finally the overall results of this study act a scientific basis to investigate the relationship between the phytochemicals of the plant extracts and the biological activities that may explore the actual antimicrobial and cytotoxic chemical constituents present in the all extracts.

\section{Conclusion}

The result displayed by the plant $A$. squamosa seed extracts both in the antibacterial bioassay and cytotoxic activity test justified the efficacy of the plant in traditional medicine which indicate that the reactions contained antibacterial agent(s) that could be effective in treatment of respiratory tract infections caused by bacteria whose chemotherapeutic index may exceed the drugs in use.

\section{References}

[1] Behera, S.K. and M.K. Misra (2005). Indigenous phyto therapy for genito-urinary diseases used by the Kandha tribe of Orissa, India. $J$. Ethnopharmacol., 102: 319-325.

[2] Chanda, S. and Y. Baravalia (2011). Brine shrimp cytotoxicity of Caesalpinia pulcherrima aerial parts, antimicrobial activity and characterization of isolated active reactions. Nat. Prod. Res. (In Press).

[3] Eloff, J.N (1998): A sensitive and quick microplate method to determine the minimal inhibitory concentration of plant extracts for bacteria. Planta Med., 64:711-713.

[4] Geethalakshmi, R., Sarada, D.V.L. and P. Marimuthu (2010). Evaluation of Antioxidant potentials of Trianthema decandra L. Asian J. of Biotechnology. 2 (4): 225-231.

[5] Harborne, J.B (1998). Phytochemical Methods - A Guide to Modern Techniques of Plant Analysis. Chapman and Hall, London. 182- 190.

[6] Meyer ,B. N., Ferrigni, N. R., Putnam ,J. E., Jacobsen, L. B., Nichols, D. E. and J. L. McLeughlin (1982). Brine shrimp: a convenient general bioassay for active plant constituents, Planta Med., 45: $31 Đ 34$.

[7] Pardhasaradhi, B.V.V., Reddy, M., Mubarak ,A.A., Kumari,A.L. and A.Khar (2005). Differential cytotoxic effects of Annona squamosa seed extracts on human tumour cell lines: Role of reactive oxygen species and glutathione. Journal of Biosciences, 30(2):237-244.

[8] Quignard, E.L, Pohlit, A.M, Nunomura, S.M, Pinto, A.C, Santos, E.V. and S.K. Morais (2003). Screening of plants found in Amazonas state for lethality towards brine shrimp. Acta Amazon. 33: 93-104.

[9] Quinlan, M.B., Quinlan, R.J. And J.M. Nolan (2004). Ethno physiology and herbal treatments of intestinal worms in Dominica, West Indies. J. Ethanopharmacol., 8075-83.

[10]Rahman, M.S. and M.A. Rashid (2008). Antimicrobial activity and cytotoxicity of Ecliptaprostrata. Oriental Pharm., Exp. Med. 8: $47-$ 52.

[11]Sheriff, N., Sudarshana, M.S., Umesha, S. and P. Prasad (2006) Antimicrobial activity of Rauvolfia tetra phyla and Physalis minima leaf and callus extracts.African Journal of Biotechnology. 5: 946-950.

[12]Tona, L., Kambu, K., Ngimbi, N., Cimang, K. and A.J. Vlietinck (1998). Antiamoebic and phytochemical screening of some Congolese medicinal plants. J. Ethnopharmacol., 61: 57-65.

[13] Yoganarasimhan, S, N. (2000). Medical Plants of India-Tamil Nadu Vol II Bangalore: International Book Publisher Print.Cyper Media: $48-62$. 